\title{
SEM TOB'S PROVERBIOS MORALES: \\ A RABBINIC VoICE FOR ANTI-RABBINIC SECTARIANISM ${ }^{1}$
}

\author{
Gregory B. Kaplan
}

Whereas the term "clérigo rabínico" (rabbinic cleric) may seem like an oxymoron, Agustín García Calvo's classification of Rabbi Sem Tob Ibn Ardutiel ben Isaac (c. 1290-c. 1369), or Sem Tob de Carrión, is justified in the case of a Jew with rabbinic training who composed his only work, Proverbios morales, in Castilian (rather than Hebrew), in the clerical cuaderna vía style. ${ }^{2}$ In addition to its cuaderna vía structure of 725 twoverse stanzas (which each contain two lines of fourteen syllables divided into two seven-syllable hemistiches), Proverbios morales shares with other mester de clerecía works a mode of oral dissemination. As Paloma Díaz-Mas explains,

it was used frequently as a liturgical or pseudo-liturgical poem. Because it was sung like a psalm during religious festivals, it was no doubt not only disseminated in written form but was also memorized and transmitted orally. ${ }^{3}$

This mode of dissemination also enlists Proverbios morales within a medieval Jewish tradition of assimilating literary texts into the liturgy as a reflection of the primacy lent to rabbinic authority. At the same time, unlike other works by medieval Jewish poets in Spain who were considered to be such authorities, Sem Tob presents an innovative perspective by voicing opposition to Rabbinism in response to his contemporary social circumstances. The popularization of Proverbios morales among Jews was a by-product of its function as a text for a

\footnotetext{
${ }^{1}$ An expanded version of this article will be published by Arc Humanities Press within a chapter of my forthcoming monograph, Jewish Poetry and Cultural Coexistence in Late Medieval Spain.

${ }^{2}$ Agustín García Calvo, ed., Glosas de Sabiduría o Proverbios Morales y otras Rimas (Madrid: Alianza, 1983), 29.

3 "fue usada con frecuencia como poesía litúrgica o paralitúrgica. Seguramente por ser cantada o salmodiada en las festividades del calendario religioso, su difusión no debió de limitarse a lo escrito, sino que también se aprendía a memoria y se transmitía oralmente" (Paloma Díaz-Mas, "Un género casi perdido de la poesía castellana medieval: la clerecía rabínica," Boletín de la Real Academia Española 73 [1993]: 341-42; the English translation is my own).
} 
Christian public, in particular King Pedro I of Castile (r. 1350-69), to whom Proverbios morales is directed. After serving during turbulent times at the court of Pedro's predecessor, Alfonso XI (r. 1312-50), Sem Tob advocates in Proverbios morales for sensible policies and toleration toward Jewish subjects. As a work that also conveys the urgency among Jews to set aside internal differences in the face of mounting antiJudaism, Proverbios morales points out lessons to be learned concerning inter-religious tensions by recalling the late medieval intra-Jewish conflict between orthodox Rabbinism and a longstanding anti-Rabbinite tradition.

The intra-Jewish conflict on which I focus traces its roots to the time of the Second Temple (516 BCE-70 CE), when the authoritative character of Rabbinism was first established among Pharisees, adherents to exegetical interpretations revealed by scholars that, according to orthodox tradition, repeated doctrines previously given to Moses along with the Written Law. Opposition to rabbinic orthodoxy evolved among sects collectively known as Sadducees, that is, followers of a strictly literal interpretation of the Pentateuch (or Written Law). The threat to Rabbinism posed by Sadducees is explained in observations made by the Romano-Jewish historian Flavius Josephus (37-c. 100) in The Jewish War:

The Sadducees, the second order, deny Fate altogether and hold that God is incapable of either committing sin or seeing it; they say that men are free to choose between good and evil, and each individual must decide which he will follow. ${ }^{4}$

In "act[ing] as they please," the dissonant Sadducees are united in their rejection of rabbinic authority. As Josephus explains in The Antiquities of the Jews, Sadducees, in opposition to Pharisees, centered this rejection on the grounds that rabbinic traditions lacked historical documentation:

The Pharisees have delivered to the people a great many observances by succession from their fathers, which are not

\footnotetext{
${ }^{4}$ Flavius Josephus, The Jewish War, intro. and trans. G. A. Williamson (Middlesex: Penguin, 1970), 130. The ancient origins of the Sadducees are indicated by Josephus in The Antiquities of the Jews (Flavius Josephus, The Antiquities of the Jews, trans. William Whiston, accessed February 18, 2015, http://www.gutenberg.org/files/2848/2848-h/2848h.htm\#link182HCH0001): "The Jews had for a great while had three sects of philosophy peculiar to themselves; the sect of the Essens, and the sect of the Sadducees, and the third sort of opinions was that of those called Pharisees" (book 18, chapter 1, paragraph 2).
} 
written in the laws of Moses; and for that reason it is that the Sadducees reject them, and say that we are to esteem those observances to be obligatory which are in the written word, but are not to observe what are derived from the tradition of our forefathers. ${ }^{5}$

Although little is known about Sem Tob's biography, I concur with Díaz-Mas that Sem Tob's rabbinic formation is revealed in his use of sources including the Old Testament, Talmud, and Maimonides (11351204). ${ }^{6}$ By the time he composed Proverbios morales around 1350 , Sem Tob would have been well versed in an age-old tradition according to which orthodox rabbinic revelations of the Oral Law were afforded primacy while those who questioned these doctrines never enjoyed the favor of authority and were at times subject to persecution by Rabbinites. ${ }^{7}$ The fact that Sem Tob composed a Hebrew penitential poem that was quickly adopted into the Sephardic liturgy as a prayer during the important festival of Yom Kippur (Day of Atonement) speaks directly to his standing as a rabbinic authority from the important Jewish center of Carrión de los Condes, and by extension as implicitly representing one side of an ancient polemic between Pharisees and Sadducees, or Rabbinites and anti-Rabbinites. ${ }^{8}$ This polemic first developed as an outgrowth of a struggle for spiritual authority, which was closely linked to political authority in ancient Israel.

After the destruction of the Second Temple in $70 \mathrm{CE}$, Jewish spiritual authority was transferred from a centralized polity governed by Mosaic Law to Mediterranean communities led by generation after generation of rabbinic scholars who deciphered the Oral Law. The widespread acceptance of rabbinic interpretations as orthodoxy empowered the rabbinate to a degree that Baruch Spinoza (1632-1677), writing in the seventeenth century, would characterize as a model for future political and religious coercion:

\footnotetext{
${ }^{5}$ Josephus, Antiquities, book 13, chapter 10, paragraph 6.

${ }^{6}$ Díaz-Mas, "Un género," 330.

${ }^{7}$ Sem Tob's allusion in Proverbios morales (v. 3a) to the death of King Alfonso XI (r. 1313-50) sets a terminus a quo for its composition of March, 1350, when Pedro I ascended the throne.

${ }^{8}$ For a study of this penitential poem, see Amparo Alba Cecilia, "El Poema penitencial de Sem Tob de Carrión," Revista de las Ciencias de las Religiones 4 (1999): 7-24.
} 
How dangerous it is to refer purely philosophical questions to divine law, and to make laws about opinions which men can or do dispute. Government is bound to become extremely oppressive where [dissident] opinions which are within the domain of each individual, a right which no one can give up, are treated as a crime.... In order to strip those who were richer than themselves of their offices, the Pharisees [or rabbis] aimed to stir up controversies about religion and accuse the Sadducees of impiety. Following the example of the Pharisees, all the worst hypocrites everywhere have been driven by the same frenzy (which they call zeal for God's law), to persecute men of outstanding probity and known virtue, resented by the common people for precisely these qualities, by publicly reviling their opinions, and inflaming the anger of the barbarous majority against them. ${ }^{9}$

The religious intimidation described by Spinoza lies at the core of his anti-Rabbinism, which is an extension of his assertion that organized religions are grounded in superstition imposed through coercion:

[Many examples] show with complete clarity that people are swayed by credulity only so long as they are afraid; that all the things they have ever worshipped under the influence of false religion are nothing but the fancies and fantasies of despondent and fearful minds; and that prophets have been most influential with the common people and most formidable to their kings when their kingdoms were in the greatest distress. ${ }^{10}$

The situation described by Spinoza characterized the political landscape of Jewish Spain. While authority was never completely in Jewish hands, on a local level the aljama, or Jewish quarter, was essentially policed by a rabbinate whose membership was frequently in direct contact with the monarchy in the role of court physician or royal advisor. These individuals could essentially attain police authority by lobbying for royal decrees that restricted conduct by Jews deemed a threat to Rabbinism.

\footnotetext{
${ }^{9}$ Benedict de Spinoza, Theological-Political Treatise, trans. Michael Silverthorne and Jonathan Israel, ed. Jonathan Israel (Cambridge: Cambridge University Press, 2007), 234. The terms "Pharisees" and "rabbis" are synonymous for Spinoza (Theological-Political Treatise, 54, 186).

${ }^{10}$ Spinoza, Theological-Political Treatise, 4-5.
} 
The medieval conflict between Rabbinites and anti-Rabbinites was exacerbated by rising interest in the figure of Anan ben David (c. 715-c. 795), who gained a following among Babylonian anti-Rabbinites from various groups, a movement that became Karaism, the expansion of which essentially renewed the process that had led to the formation of the Sadducees in ancient times. As its growth was fueled by contact with Muslim scholars and theologians working to develop doctrines that questioned monolithic orthodoxy, Karaism "unite[d] under its aegis the chief opposition to the central controls administered by exilarchs and academies in the name of the Talmud." detected by the Muslim historian and theologian Ibn Hazm (994-1064), who observes that Karaism had acquired a following among Jews in the important urban centers of Toledo and Talavera. ${ }^{12}$

The perceived magnitude of the Karaite threat informs The Book of Tradition (1160-61) by the Cordovan historian and philosopher Abraham ibn Daud (c. 1110-c. 1180). The Book of Tradition is the most important medieval work against Jewish sectarianism and an ardent defense of an uninterrupted rabbinic tradition since biblical times. Daud sacrifices historical accuracy to achieve his main goal of establishing the continuity of Rabbinic Judaism, and it may be said that he is motivated more by a desire to put a quick end to what he saw as a long-standing threat than an attempt to engage in a polemic concerning particular Karaite doctrines. The popularity of Karaism is thus greatly diminished by Daud, who conflates Sadducees and Karaites, provides an anachronistic account of the birth of the Karaite movement in Spain immediately after situating the sect in ancient Israel, and claims that Rabbi Joseph ha-Nasi Ibn Ferruziel (d. c. 1145), a royal physician to Alfonso VII of Castile (r. 1126-57), all but eliminated the presence of Karaism in Castile:

When the Jews used to celebrate the festival of Tabernacles on the Mount of Olives, they would encamp on the mountain in groups and greet each other warmly. The heretics would encamp before them like two little flocks of goats. Then the rabbis would take out a scroll of the Torah and pronounce a ban on the heretics right to their faces, while the latter remained silent like dumb dogs.

\footnotetext{
${ }^{11}$ See Salo Wittmayer Baron, A Social and Religious History of the Jews, vol. 9, 2nd ed. (New York: Columbia University Press, 1965), 230.

${ }^{12}$ For an English translation of Ibn Hazm, see Abraham ibn Daud, The Book of Tradition, intro. and trans. Gerson D. Cohen (Philadelphia: Jewish Publication Society of America, 1967), xlvi.
} 
Among those [heretics] living in the Holy Land there was alSheikh Abu'l-Faraj, may his bones be committed to hell. It happened that a certain fool from Castile, named Cid Abu'l Taras, went over there and met the wicked al-Sheikh Abu'l-Faraj, who seduced him into heresy. Under the guidance of the latter, Abu'lTaras composed a work animated by seduction and perversion, which he introduced into Castile and [by means of which] he led many astray. When Abu'l Taras passed on to hell, he was survived by his accursed wife, whom [his adherents] used to address as al-Mu allima and on whom they relied for authoritative tradition. They would ask each other what $M u$ allima's usage was, and they would follow suit. [This went on] until the rise to power of the Nasi R. Joseph b. Ferruziel, surnamed Cidellus, who suppressed them even beyond their former lowly state. He drove them out of all the strongholds of Castile except for one, which he granted them, since he did not want to put them to death (inasmuch as capital punishment is not administered at the present time). However, after his death, the heretics erupted until the reign of King Don Alfonso son of Raimund, king of kings, the Emperador. In his reign there rose nesiim who pursued the ways of their fathers and suppressed the heretics [again]. ${ }^{13}$

In spite of efforts by the rabbinate to suppress it, the resurgence of Karaism in Spain persisted during the twelfth and thirteenth centuries. In Castile, the popularization of Karaism caused the rabbinate to seek royal support for the expulsion of Karaites from public places, which was decreed in 1109. However, the repetition of this decree in 1148 reflected the continued popularity of Karaism in places such as Sem Tob's home town of Carrión de los Condes, where Karaites were ordered to adopt orthodox norms according to a royal decree of 1178 that was secured through rabbinic influence at court.

The rabbinic suppression of Karaism codified by Daud is used as a tool for fomenting anti-Rabbinic and, in a broader context, anti-Jewish sentiment in Mostrador de justicia by Abner de Burgos (c. 1270-c. 1347), a Jewish theologian who converted to Christianity around 1330 and became a renowned anti-Jewish polemicist. In effect, Abner hijacks the anti-Rabbinic critique of the Sadducees to attack Judaism as a whole.

\footnotetext{
${ }^{13}$ Daud, The Book of Tradition, 94-95.
} 
Abner reveals early on that one of his principal motives for composing Mostrador de justicia is to loosen the grip of Rabbinic authority:

Most of the Jews believe in the teachings of their Talmudic sages, and only very few dare to go against those sages. Therefore, their disrepute becomes greater when we find evidence against them based on their great sages whom they revere and honor. ${ }^{14}$

Abner inherits from Daud (whose Book of Tradition is cited on a number of occasions in Mostrador de justicia) the tendency toward anachronistic accounts of historical anti-Rabbinism. Abner thus depicts Sadducees as a continuation of a biblical tradition, and Sadducees, rather than Karaites, inhabit the Castilian towns of Carrión de los Condes and Burgos. Abner groups all anti-Rabbinites as heretics and points out that the expression of this sizeable group ("muchos omnes que niegan el ssu Talmud dellos" ["many men who deny their Talmud"]) is suppressed:

It is said that the Jewish heretic, the one who rejects what the Jews have received from their ancestors ... cannot be straightened out for any reason shared by other Jews, who disdain and cast doubt on the view of those who deny what has been understood, even those things that could straighten them out [i.e., the heretics] and resolve their doubts. This explains why there are found among the Jews many men who deny the Talmud. ${ }^{15}$

Abner's desire to exploit tensions between Rabbinites and antiRabbinites is evident on other occasions in Mostrador de justicia. In his seminal study A Social and Religious History of the Jews, Salo Wittmayer Baron suggests an influence of Karaism on the last chapter of

\footnotetext{
14 “Los más de los judios creen en los dichos de ssus ssabios del Talmud, e muy pocos sson dellos que ossan yr contra aquellos sabios. Por ende enfforçarsse-a la nuestra rrazon contra ellos quando nos aduremos prueuas contra ellos de los sus grandes ssabios abtenticos e onrrados entrellos" (Abner of Burgos [Alfonso de Valladolid], Mostrador de justicia, ed. Walter Mettman, 2 vols. [Opladen: Westdeutscher Verlag, 1994-96], 1: 43; the English translation is my own).

15 "Como que diz que el ereje judio, el que despreçia en lo que tienen rresçebido los judios de ssus anteçessores ... tal omne como éste non puede auer endereçamiento por ninguna rrazon quel rrazonassen los otros judios, despues que desdennan e ponen dubda en sus opiniones rresçebidas dellos e que niega[n] las opiniones entendidas, las que podrian endereçar e ssoltar ssus dubhas. E por esto sson fallados en los judios muchos omnes que niegan el ssu Talmud dellos” (Abner of Burgos, Mostrador de justicia 2: 419).
} 
Abner's text: "This chapter, devoted to a detailed critique of the Maimonidean Code, bears many similarities with the attacks on Rabbinite law by Karaites." 16 More recently, Ryan Szpiech depicts Abner's attitude in terms that recall the attacks on the Rabbinic tradition leveled since the time of the Sadducees:

Rather than attacking the Rabbinical writing or his Jewish reader directly, however, he instead faults the early rabbis who, he claims, knew that Jesus was the expected Messiah but refused to teach others what they discerned in Scriptures and traditional authorities. They did this not out of ignorance but out of their ill will against Jesus. This deliberate concealment by the original sages was then perpetuated by later Jewish leaders and handed down as tradition within the Jewish community, and it is up to the righteous individual Jew to break this transmission and fix his own tradition. ${ }^{17}$

Abner's reverence for Karaite anti-Rabbinism in response to what Szpiech describes as a "deliberate concealment by the original sages," or rabbinic intimidation, fuels a dialogue between Mostrador de justicia and Proverbios morales that springs from the adversarial relationship between Abner and Sem Tob described by Sanford Shepard: "The persistence of Karaite tendencies had a notable effect on Abner of Burgos ... whose polemic against Judaism [Mostrador de justicia] exerted a profound influence on Shem Tov's literary works." ${ }^{18}$ Similarly, Theodore Perry posits that Sem Tob responded to "the danger of the Jewish informer to the gentile authorities, such as Abner of Burgos" when he depicted the rise to power of the vile man in Proverbios morales: ${ }^{19}$

The vile man acts in the opposite way: lowering himself to those greater than he, he acts high and mighty with his inferiors.

\footnotetext{
${ }^{16}$ Baron, A Social and Religious History of the Jews, 305, n. 32.

${ }^{17}$ Ryan Szpiech, Conversion and Narrative: Reading and Religious Authority in Medieval Polemic (Philadelphia: University of Pennsylvania Press, 2012), 153.

${ }^{18}$ Sanford Shepard, Shem Tov: His World and His Words (Miami: Universal, 1978), 16. With regard to what I term "reverence" for Karaite anti-Rabbinism, Shepard writes: "Abner revived the slumbering rationalism of the Karaites that had been utilized before to call into question the authority of the Talmud" (Shepard, Shem Tov, 29).

${ }^{19}$ T. A. Perry, The Moral Proverbs of Santob de Carrión: Jewish Wisdom in Christian Spain (Princeton: Princeton University Press, 1987), 129, n. 32.
} 
He portrays his bad fortune as more than twice as bad as it really is, and in good fortune he astounds everyone.

When his luck is bad, he is lower than the earth; but in good times he challenges heaven itself.

He who would like to hear the reputation of the vile man so as to recognize him openly when he sees him:

He does nothing on request but submits to force; break him and he will immediately obey you.

I consider him as a bow in all his activities; for until he is bent he can do no good.

It is worse when an evil man rises up among the people, much worse than when ten righteous men perish.

For when the good perish, certainly goodness is diminished; but the harm is less than when evil increases.

It is when the great man falls that the lowly one rises up; the fire that goes out gives life to the smoke.

[However,] the falling of the dew [also] causes grass to sprout; the servants derive their honor from the standing of their master. $^{20}$

The theories of Shepard and Perry are borne out by a comparative analysis of Sem Tob's "vyllano," or "vile man," who is presented in contrast to the "omre noble," or "noble man." Sem Tob writes that "the noble man is accustomed to raise himself up to the great of this world and to show himself humble and docile with the lowly. He shows his greatness to strangers and shows great humility to those that have fallen

\footnotetext{
20 "Su rrebes del vyllano: Baxas a los mayores, / E alto e loçanoSe faz a los menores. / Mas de quanto es, dos tanta, Muestra su mal andança, / E al mundo espanta En la su buena andança. / En la su mal andança Es mas baxo que tierra, / E en su buena andança Al çielo quier dar guerra. / El que oyr quisyere Las mañas del villano, / Por que quando lo vyere Lo conoçca de mano: / Non faz cosa por rruego, E la premia consyente: / Castigalo, e luego Te sera obediente. / Com el arco le cuento Yo en todo su fecho: / Fasta quel fazen tuerto, El nunca faz derecho. / Peor es lebantarse Vn malo en la gente. / Mucho mas que perderse Diez buenos, çierta mente. / En perderse los buenos, çierto el bien falleçe, / Pero el dañu menos Es que quando mal creçe. / Quando el alto cae, El baxo se lebanta: / Vida al fumo trae El fuego que se amata. / El caer del rroçio Faz lebantar las yerrbas, / Onrranse con el peçio De la señor las syerbas" (Sem Tob de Carrión, Proverbios morales, ed. Sanford Shepard [Madrid: Castalia, 1985], st. 287-96). The English translation is by Perry (Moral Proverbs, 34).
} 
low" 21 ; the vile man "astounds everyone" 22 and "challenges heaven itself." ${ }^{23}$ Whereas Sem Tob guides the reader toward the behavior of the noble man, he also draws attention to the success of the vile man, whose actions are not examples to follow because they contribute to social discord, which is, in turn, a component of Sem Tob's broader message to King Pedro. By extension, it may also be argued that Sem Tob endeavors to recall sectarian oppression in order to warn against its being directed toward Jews. In other words, Sem Tob is reminding Jews of the danger of allowing sectarian divisions to legitimize anti-Jewish persecution in Christian eyes.

Sem Tob's depiction of the vile man begins by symbolically recalling the social circumstances described by Abner: "The vile man acts in the opposite way: lowering himself to those greater than he, he acts high and mighty with his inferiors. ${ }^{24}$ By declaring that vileness is achieved by "act[ing] in the opposite way [and] lowering himself to those greater than he," Sem Tob points to the process by which the flames of Christian anti-Judaism were ignited through Abner's depiction of sectarian persecution. Abner's aforementioned declaration that only few dare to challenge the rabbinate evokes the fact that these challenges were met with harsh retribution, which ultimately stirred anti-Jewish sentiment, a situation that Sem Tob also recalls for his Jewish and royal publics as a means of demonstrating "the potential harm from such an individual to the entire community." 25 Abner's efforts were successful, and in 1336 he "obtained a decree from Alfonso XI requiring the examination of Hebrew books for alleged blasphemy against Jesus and the Holy Family."26

\footnotetext{
21 "el omre noble / A los altos alçarse, / Synple e conuenible / A los vaxos mostrarse. / Muestra la su grandeza / A los desconoçidos, / E la su gran sympleza / A los baxos caydos" (Sem Tob, Proverbios morales, st. 283-84). The English translation is by Perry (Moral Proverbs, 33).

22 "al mundo espanta"(Sem Tob, Proverbios morales, st. 288). The English translation is by Perry (Moral Proverbs, 34).

23 "Al çielo quier dar guerra" (Sem Tob, Proverbios morales, st. 289). The English translation is by Perry (Moral Proverbs, 34).

24 "Su rrebes del vyllano: / Baxas a los mayores, / E alto e loçano / Se faz a los menores" (Sem Tob, Proverbios morales, st. 287). The English translation is by Perry (Moral Proverbs, 34).

${ }^{25}$ Perry, Moral Proverbs, 129.

${ }^{26}$ Shepard, Shem Tov, 28.
} 
Perry explains that similar harm could result from "the crucial moment of ... the transfer of royal power" to a king who might issue anti-Jewish decrees, although such harm could also be produced through acts committed by Jews against Jews. ${ }^{27}$ In 1109 , a figure evoked by the "vile man" of Sem Tob for "lowering himself to those greater than he" was the previously mentioned Rabbi Ferruziel, who conducted his attack on Karaites by personally subjecting them to "all types of humiliation."28 This mortification of Karaites was essentially repeated when, after Karaites had regrouped in the early 1100s, Rabbi Yehuda ben Ezra, the royal steward to Alfonso VII of Castile, "asked the king not to permit the heretics to speak throughout Castile." ${ }^{29}$ In the wake of the success of Karaism in Carrión de los Condes, it was the royal physician, Josef Alfácar, who obtained a royal decree from Alfonso VIII (r. 1158-1214) that forced Rabbinism on Karaites.

While they are known historically as "noble men"-for example, the quasi epic figure of Rabbi Joseph ha-Nasi Ibn Ferruziel earned the epithet Cidellus, or "little Cid," and helped many Jews escape to northern Spain from increasingly intolerant Islamic rule in the south-the involvement of Ferruziel, Ben Ezra, and Alfácar in obtaining royal sanction of the oppression of Karaites is, according to Sem Tob's reasoning, "the opposite way" (v. 1081) of the noble behavior that he describes in the verses cited above ("The noble man is accustomed to raise himself up to the great of this world and to show himself humble and docile with the lowly. He shows his greatness to strangers and shows great humility to those that have fallen low"). The lack of humility displayed by Ferruziel, Ben Ezra and Alfácar is condemned by Sem Tob, as it is by Abner, albeit for different motives. Abner endeavors to underscore the fact that Jewish sectarianism was met with rabbinic oppression in order to provide an insider's perspective as ideological fuel for enhancing an extant anti-Jewish animus.

For Sem Tob, the veiled reference to questionable acts performed by respected rabbis is a condemnation of the use of intimidation to quell sectarian sentiment as well as a call for royal tolerance. The urgency of

\footnotetext{
${ }^{27}$ Perry, The Moral Proverbs, 129.

28 “toda clase de humillaciones." Qtd. in Carlos Sáinz de la Maza, "Alfonso de Valladolid y los caraítas: Sobre el aprovechamiento de los textos históricos en la literatura antijudía del siglo XVI," El Olivo 31 (1990): 19; the English translation is my own.

29 "pidió al rey que no dejara abrir la boca a los herejes en toda la tierra de Castilla." Qtd. in Sáinz de la Maza, "Alfonso de Valladolid," 19-20; the English translation is my own.
} 
this call responded to the fear that King Pedro would inherit the posture of his father, Alfonso XI, who was at times intolerant toward Jews. Indeed, after one anti-Semitic episode at the royal court in the 1330s, Sem Tob was "in imminent danger of arrest." $"$ In light of increasing popular anti-Judaism tied to a variety of factors, including outbreaks of the Black Plague, economic crises, and a negative perception of Jews with respect to the dominant Christian culture (a notion whose public dissemination by the Dominicans and Franciscans is studied by Jeremy Cohen), the words of both Abner and Sem Tob ultimately proved forewarning. ${ }^{31}$ Abner influenced other apostates such as Pablo de Santa Maria (c. 1351-1435) - the name adopted by Rabbi Solomon ha-Levi of Burgos after his conversion to Christianity-who oversaw the forced conversion of thousands of Jews in 1391 after a wave of anti-Jewish pogroms by the Christian population, which created a caste of neophytes whose descendants continued to carry the indelible stigma of a Jewish ancestry as inferior New Christians (conversos) with respect to Old Christians, and which initiated the process leading to the expulsion of Spain's Jews in 1492.

The high importance to Jews of perpetuating the wisdom offered by Sem Tob is demonstrated by the translation of Proverbios morales into aljamiado, or Spanish written in Hebrew characters, within a century after its composition. ${ }^{32}$ For Jews on the eve of Sephardic diaspora, Sem Tob's wisdom was maintained through memorization of Proverbios morales as exemplified by the fact that one of the manuscripts is a transcription by an inquisitor of the Spanish Inquisition of a lengthy component of the work that forms part of oral testimony made in 1492 by a converso, Ferrán Verde. ${ }^{33}$ Testimony of the importance of the legacy of Sem Tob is also revealed in an anonymous Castilian prologue to Proverbios morales composed during the fifteenth century: "For, without doubt, these verses are notable writings which every person should learn by heart. For this was the intent of the wise Rabbi who made them, since

\footnotetext{
${ }^{30}$ Shepard, Shem Tov, 14.

${ }^{31}$ See Jeremy Cohen, The Friars and the Jews: The Evolution of Medieval Anti-Judaism (Ithaca: Cornell University Press, 1982).

${ }^{32}$ For a discussion of the extant manuscripts of Proverbios morales, see Paloma DíazMas and Carlos Mota, eds. Proverbios morales (Madrid: Cátedra, 1998), 11-16.

${ }^{33}$ Shephard posits that this testimony pertains to a "longstanding oral tradition" ("larga tradición oral" [Sem Tob, Proverbios morales, 74]).
} 
poetry is more easily memorized than prose." 34 The anonymous author evokes Sem Tob's message against combating sectarian discord with religious oppression by declaring,

the knowledgeable man should not stop teaching his knowledge from fear of suffering difficulties and pain, all the more so because it is known that this [knowledge] comes to the man who has it from divine inspiration. ${ }^{35}$

Further on, the anonymous author justifies the existence of sectarianism: "Since the Lord God gives wisdom to one so that it can be taught to many, in the same way He could give it [directly] to the many." ${ }^{36}$ For all intents and purposes, this attitude lends primacy to the toleration of sectarian rifts in the spirit of preserving social harmony.

When David Wacks asserts in his recent monograph that Sem Tob "invited the audience to consider a world of relativism and pluralism, to hold the contradiction that there may be more than one way to understand this world," he is the latest scholar to underscore a common topos in the works of Sem Tob, namely, the presentation of both sides of a polemic. ${ }^{37}$ Like the Libro de buen amor by his Christian contemporary Juan Ruiz (fl. early 14th c.), Sem Tob's clerecía text can be understood from contradictory perspectives. ${ }^{38}$ Sem Tob's rabbinic voice thus articulates a

\footnotetext{
34 "Por cuanto syn dubda las dichas trobas son muy notable escritura, que todo omne la deuiera decorar. Ca esta fue la entençion del sabio Raby que las fizo, por que escritura rimada es mejor decorada que non la que va por testo llano" (Perry, Moral Proverbs, 171; the English translation is by Perry, Moral Proverbs, 174).

35 "E por esto non deue çesar de fablar çiençia el que sabe, por cuyta de sofrir trabajos o dolor. Mayormente que es notorio que uyene por devyna ynfluyda de Dios enel omne que la ha" (Perry, The Moral Proverbs, 170; the English translation is by Perry, The Moral Proverbs, 173).

36 "pues el señor Dios, commo da la sabiduria a uno para enseñarla a muchos, tan bien la podria dar a los muchos" (Perry, The Moral Proverbs, 170; the English translation is by Perry, The Moral Proverbs, 173).

${ }^{37}$ David A. Wacks, Double Diaspora in Sephardic Literature (Bloomington: Indiana University Press, 2015), 109. Clark Colahan and Alfred Rodríguez describe the ambiguous tone of Proverbios morales in the following terms: "Sem Tob frequently presents opposing points of view and, in keeping with his perception of the relativity of human experience, more than once systematically gives first the arguments for one position and then those for the opposite stance, resolving the conflict only to the extent of endorsing the golden mean" (Clark Colahan and Alfred Rodríguez, "Traditional Semitic Forms of Reversibility in Sem Tob's Proverbios morales," Journal of Medieval and Renaissance Studies 13.1 [1983]: 33).

${ }^{38}$ On the multiple interpretations of Juan Ruiz's Libro de buen amor, see Colahan and Rodríguez ("Traditional Semitic Forms") and Marina Scordilis Brownlee, The Status of the
} 
rare example of a liturgical poem not only because it is in Spanish, unlike the numerous piyutim (Jewish liturgical poems) adopted from the Hebrew works of medieval Iberian Jewish authorities such as Judah haLevi (c. 1085-1140) and Abraham ibn Ezra (1089-c. 1167), but because it also presents a plea for overcoming sectarian tensions. It is precisely this multiplicity of interpretations that would have enabled Jewish and converso readers to recognize that Sem Tob means to be inclusive rather than restrictive and urges toleration of internal discord so as to preserve social harmony. This toleration lies at the core of Sem Tob's response to Abner's inflammatory tone, as he announces early on in Proverbios morales:

I wish to speak, concerning the world and its ways and my doubts about it, very truthful words.

For I am unable to find a mean or reach any decision; I retreat from more than a hundred resolutions every day.

What one man denigrates I see another praise; what this one considers beautiful another finds ugly.

The measuring rod that the buyer calls short, this same rod is called long by the seller.

The one who throws the spear considers it slow, but the man that it reaches finds it speedy enough. ${ }^{39}$

Insofar as multiple interpretations are valid, any Jew might extract a correct one, which explains how Proverbios morales could form a part of the Sephardic liturgy and also be a text memorized by conversos as an expression of a waning Jewishness that they sought to preserve in inquisitorial Spain. During the historical moment when Proverbios morales was composed, only several years before escalating popular antiJewish sentiment would result in the first pogrom, which was launched in

Reading Subject in the Libro de buen amor (Chapel Hill: University of North Carolina Press, 1985).

39 "Quiero dezyr del mundo E de las sus maneras, / E commo del dubdo Palabras muy çerteras. / Que non se tomar tiento Nin fazer pleytesia; / De acuerdos mas de ciento Me torno cada dia. / Lo que vno denuesta, Veo a otro loarlo; / Lo que este apuesta, Veo a otro afearlo. / La vara que menguada La diz el conprador, / Esta mesma sobrada La diz el vendedor. / El que lança la lança Semeja la vaguarosa, / Pero al que alcança Semeja le presurosa" (Sem Tob, Proverbios morales, st. 70-74; the English translation is by Perry, Moral Proverbs, 20). 
1355 in Toledo because of the perceived roles of Jewish agents of the government in royal oppression, Sem advocates the necessity of setting aside differences. ${ }^{40}$ It is logical to speculate that this need was in the process of being shared by both orthodox and Karaite Jews whose communities throughout Iberia were decades away from being decimated by violence and mass conversions to Christianity. Sem Tob's call for tolerance in Proverbios morales suggests that he felt that it was a message that not only needed to be delivered to the king but to his fellow Jews as well.

University of Tennessee

${ }^{40}$ For a review of the development of this popular anti-Jewish animus, see Gregory B. Kaplan, The Evolution of Converso Literature: The Writings of the Converted Jews of Medieval Spain (Gainesville: University Press of Florida, 2002), 16-19. 


\section{Bibliography}

Abner of Burgos/Alfonso de Valladolid. Mostrador de justicia. Edited by Walter Mettman. 2 vols. Opladen: Westdeutscher Verlag, 1994-96.

Baron, Salo Wittmayer. A Social and Religious History of the Jews. Vol. 9. 2nd ed. New York: Columbia University Press, 1965.

Brownlee, Marina Scordilis. The Status of the Reading Subject in the Libro de buen amor. Studies in the Romance Languages and Literatures no. 22. Chapel Hill: University of North Carolina Press, 1985.

Cecilia, Amparo Alba. "El Poema penitencial de Sem Tob de Carrión." Revista de las Ciencias de las Religiones 4 (1999): 7-24.

Cohen, Jeremy. The Friars and the Jews: The Evolution of Medieval Anti-Judaism. Ithaca: Cornell University Press, 1982.

Colahan, Clark, and Alfred Rodríguez. "Traditional Semitic Forms of Reversibility in Sem Tob's Proverbios morales." Journal of Medieval and Renaissance Studies 13.1 (1983): 33-50.

Daud, Abraham ibn. The Book of Tradition: Sefer ha-Qaballah. Introduction and translation by Gerson D. Cohen. Philadelphia: Jewish Publication Society of America, 1967.

Díaz-Mas, Paloma. "Un género casi perdido de la poesía castellana medieval: la clerecía rabínica." Boletín de la Real Academia Española 73 (1993): 329-46.

- , and Carlos Mota, eds. Proverbios morales by Sem Tob de Carrión. Madrid: Cátedra, 1998.

García Calvo, Agustín, ed. Don Sem Tob: Glosas de Sabiduría o Proverbios Morales y otras Rimas. Madrid: Alianza, 1974.

Josephus, Flavius. The Antiquities of the Jews. Translated by William Whiston. New York : Ward, Lock, Bowden, 1900 [?]. http://www. gutenberg.org/files/2848/2848-h/2848-h.htm\#link182HCH0001. Accessed February 18, 2015.

-. The Jewish War. Introduction and translation by G. A. Williamson. Middlesex: Penguin, 1970.

Kaplan, Gregory B. The Evolution of Converso Literature: The Writings of the Converted Jews of Medieval Spain. Gainesville: University Press of Florida, 2002. 
Perry, T. A. The Moral Proverbs of Santob de Carrión: Jewish Wisdom in Christian Spain. Princeton: Princeton University Press, 1987. https://doi.org/10.1515/9781400859146

Ruiz, Juan. Libro de buen amor. Edited by Alberto Blecua. Madrid: Cátedra, 1992.

Sáinz de la Maza, Carlos. "Alfonso de Valladolid y los caraítas: Sobre el aprovechamiento de los textos históricos en la literatura antijudía del siglo XVI." El Olivo 31 (1990): 15-32.

Sem Tob de Carrión. Proverbios morales. Edited by Sanford Shepard. Madrid: Castalia, 1985.

Shepard, Sanford. Shem Tov: His World and His Words. Miami: Universal, 1978.

Spinoza, Benedict de. Theological-Political Treatise. Cambridge Texts in the History of Philosophy. Translated by Michael Silverthorne and Jonathan Israel. Edited by Jonathan Israel. Cambridge: Cambridge University Press, 2007.

Szpiech, Ryan. Conversion and Narrative: Reading and Religious Authority in Medieval Polemic. The Middle Ages Series. Philadelphia: University of Pennsylvania Press, 2012.

Wacks, David A. Double Diaspora in Sephardic Literature. Bloomington: Indiana University Press, 2015. 